\title{
The Pacific Equatorial Age Transect, IODP Expeditions 320 and 321: Building a 50-Million-Year-Long Environmental Record of the Equatorial Pacific Ocean
}

\author{
by Mitchell Lyle, Heiko Pälike, Hiroshi Nishi, Isabella Raffi, Kusali Gamage,
} Adam Klaus, and the IODP Expeditions 320/321 Scientific Party

doi:10.2204/iodp.sd.9.01.2010

\section{Introduction}

In March 2009, the R/V JOIDES Resolution returned to operations after its extended refit and began with a drilling program ideally suited to its drilling strengths, the Pacific Equatorial Age Transect (PEAT, IODPExp 320/321; Fig. 1A). The PEAT drilling program was developed to understand how a major oceanic region evolved over the Cenozoic Era (65-0 Ma) and how it interacted with global climate. It specifically targeted the interval between $52 \mathrm{Ma}$ and $0 \mathrm{Ma}$ and drilled a series of sites that originated on the paleoequator. These sites have since been moved to the northwest by plate tectonics.
The equatorial Pacific is an important target for paleocean ographic study because it is a significant 'cog' in the Earth's climate machine, representing roughly half of the total tropical oceans that in turn represent roughly half of the total global ocean area. Prior drilling in both the Deep Sea Drilling Project (DSDP) and the Ocean Drilling Program (ODP) outlined the changes that have occurred through the Cenozoic (e.g., van Andel et al., 1975; Pisias et al., 1995). Not only did the earlier work fail to cover sufficient time intervals but also many of the sites were cored with 'first-generation' scientific drilling technology with incomplete and disturbed sediment recovery and thus cannot be used for detailed studies.

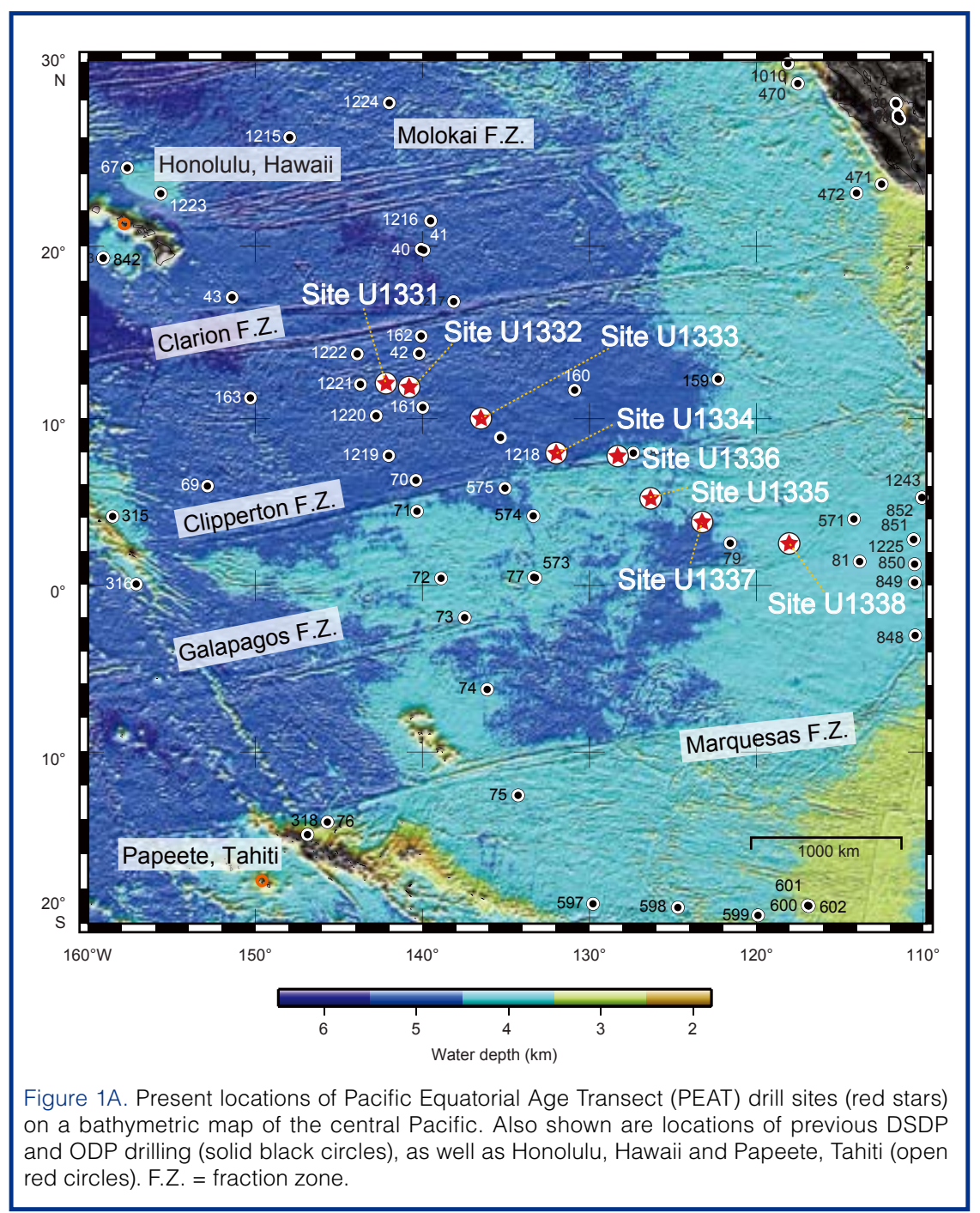

ODP Legs 138 and 199 provide the best sample material from previous drilling, but each leg recovered sections spanning less than 10 million years suitable for cyclostratigraphy (the use of earths orbital cycles, recorded in sediments, as a measure of time). Up until the PEAT program it was difficult to achieve more than a reconnaissance of the environmental changes that have occurred in the equatorial Pacific. The PEAT program was designed to augment previous drilling and collect undisturbed sediments that could be spliced into a continuous, high-resolution environmental record of the eastern equatorial Pacific for the entire period from $56-0 \mathrm{Ma}$ to present.

\section{Why Study the Eastern Equatorial Pacific?}

As the world's largest ocean, the Pacific Ocean is intricately linked to major global changes that took place during the Cenozoic. The equatorial Pacific is a major area for trapping of incoming solar radiation (Bryden and Brady, 1985), a major zone of high primary productivity (Chavez and Barber, 1987; Westberry et al., 2008), and an important region for $\mathrm{CO}_{2}$ exchange from the deep ocean to the atmosphere (Takahashi et al., 1997). 
It is also the source of one of the strongest modern inter-annual climate oscillations, the El Niño-Southern Oscillation (ENSO, Philander, 1983; Cane and Zebiak, 1985). Furthermore, previous work has shown that the equatorial Pacific west of the East Pacific Rise $\left(100^{\circ} \mathrm{W}\right)$ coherently responds over distances $>1000 \mathrm{~km}$ on timescales as short as ENSO (Philander, 1983) and as long as millions of years (Mayer et al., 1986; Shackleton et al., 1995; Pälike et al., 2005). It also has been established, largely via scientific drilling, that there have been large-scale, global changs in climate over the Cenozoic that affected the equatorial Pacific (van Andel et al., 1975; Mayer et al., 1986; Pisias et al., 1995; Zachos et al., 2001a; ODP Leg 199 Shipboard Scientific Party, 2002; Zachos et al., 2008).

The circulation of the equatorial surface ocean is inescapably linked to the trade wind system. The equatorial Pacific is the classic "world ocean" example of this linkage; it is dominated by wind-driven circulation and is largely unfettered by ocean boundaries. Here, the equator itself is characterized by a narrow zone of divergence that results from the change in the sign of the Coriolis Effect and that gives rise in the modern world to a band of high biologic productivity within a $2^{\circ}$ latitudinal band of the equator (Fig. 1B). The strength of the equatorial circulation and of this divergence

is linked to the strength of the trade winds, which are in turn strongly tied to the global climate system. Variations in global climate, inter-hemispheric differences in temperature gradients, and marked changes in the ocean boundaries are all imprinted on the biogenic-rich sediments accumulating in the equatorial zone.

Finally, the equatorial Pacific may have responded to the closing of Tethys gateways, potentially a significant Cenozoic climate driver. Closure of the Panama gateway and the constriction of the Indonesian Passage should both have affected the Pacific, and indeed, evidence for oceanographic change associated with these gateway restrictions are recorded in

\section{PEAT Science Objectives:}

To detail the nature and changes of the carbonate compensation depth (CCD) over the Cenozoic in the paleoequatorial Pacific

To determine the evolution of paleoproductivity of the equatorial Pacific over the Cenozoic

3. To validate and extend the astronomical calibration of the geological timescale for the Cenozoic, using orbitally-forced variations in sediment composition known to occur in the equatorial Pacific, and to provide a fully integrated and astronomically calibrated bio-, chemo-, and magnetostratigraphy at the equator

4. To determine temperature (sea-surface and bottom water), nutrient profiles, and upper water column gradients

5. To better constrain Pacific plate tectonic motion and better locate the Cenozoic equatorial region in plate reconstructions, primarily via paleomagnetic methods

6. To make use of the high level of correlation between tropical sedimentary sections and existing seismic stratigraphy to develop a more complete model of equatorial circulation and sedimentation

7. To provide information about rapid biological evolution and turnover rates during times of climatic stress

8. To improve our knowledge of the reorganization of water masses as a function of depth and time, as the PEAT drilling strategy also implies a paleodepth transect

9. To develop a limited N-S transect across the paleoequator, caused by the northward offset of the proposed sites by Pacific plate motion, providing additional information about $\mathrm{N}-\mathrm{S}$ hydrographic and biogeochemical gradients

10. To obtain a transect of mid-ocean-ridge basalt (MORB) samples from a fixed location in the absolute mantle reference frame, and to use a transect of basalt samples along the flowline that have been erupted in similar formation-water environments to study low-temperature alteration processes by seawater circulation 
Neogene equatorial Pacific and Caribbeansediments (Keigwin, 1982; Romine and Lombari, 1985; Lyle et al., 1995; Haug and Tiedemann, 1998; Roth et al., 2000; Cane and Molnar, 2001; Lyle et al., 2008).

\section{Design of the PEAT Drilling Program}

The primary design criterion of PEAT drilling was to recover sediments deposited in the equatorial zone during different time slices of the Cenozoic and assemble them into an equatorial Pacific 'megasplice' covering the interval from $56 \mathrm{Ma}$ to present. The sedimentary records from "off-splice" latitudes are not ignored, but they give important insight into the strength of winds, currents, upwelling, productivity, and changes in

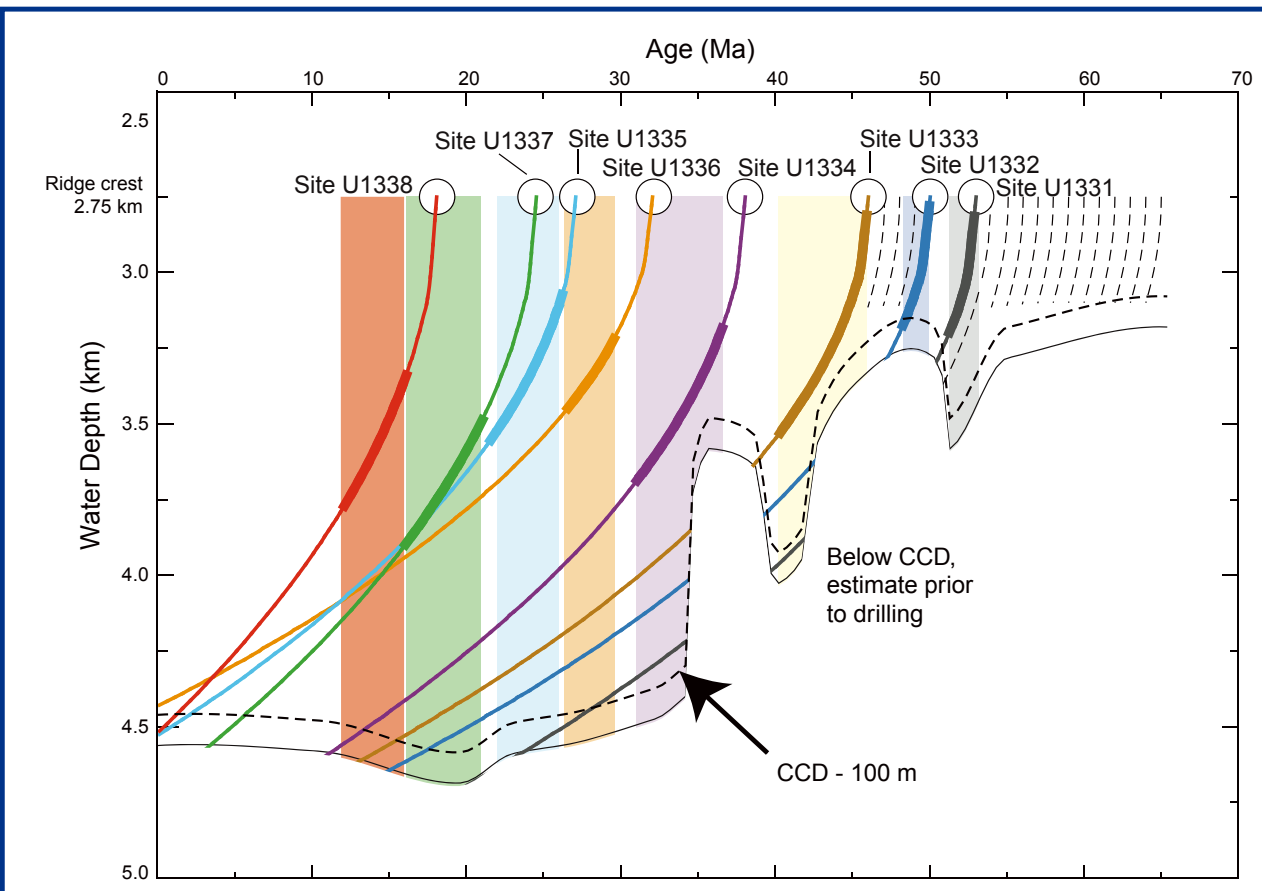

Figure 2. Targeting drill sites prior to coring based on calcium carbonate compensation depth (CCD) history (van Andel, 1975), with additional data from Leg 199. Colored boxes = critical time interval targeted for each site. Colored subsidence lines are critical time intervals where we also expected carbonate to be deposited (i.e., when site is above CCD). Subsidence curves use a subsidence parameter calculated from estimated basement age of PEAT sites and their present-day depth $(k=\sim 0.35)$. Additional subsidence due to sediment loading was not modeled. carbonate compensation depth (CCD) once the chronostratigraphy is properly calibrated (Hovan, 1995; Lyle, 2003; Moore et al., 2004). The off-equatorial sediments are also important for calibration of paleomagnetic stratigraphy with well-developed equatorial Pacific biostratigraphy (Schneider, 1995; Lanci et al., 2005). Text box on the previous page provides the scientific objectives for the PEAT program.

Tectonic motions of the Pacific plate help to make the equatorial Pacific an attractive target for recovery of environmental records. The Pacific plate has moved with a northward latitudinal component of around $0.25^{\circ}$ m.y. ${ }^{-1}$ for the last 43 million years, and it moved slightly faster to the north prior to that time (Koppers et al., 2001). The north-west movement of the Pacific plate transports the equatorial sediments gradually out from under the zone of highest primary productivity at the equator, resulting in a broad mound of biogenic sediments (Fig. 1B). The transport of crust away from this equatorial zone of rapid sedimentation into regions with lower sedimentation rates keeps older equatorial sediment sections from being buried deeply beneath younger sediments. However, this tectonic movement requires that a complete environmental record of the equatorial region must be spliced together from different drill sites. Assembling a complete equatorial record requires periodic shifts to new drill site locations that contain sediments of the appropriate age deposited within the equatorial zone (Fig. 1).

While the tectonic transport of each drill site complicates reconstruction, the diminished overburden resulting from

transport out of the relatively fast sedimentation regime near the equator also minimizes potential burial diagenesis and allows for good preservation of biogenic sediments. In addition, because of the shallow overburden, most of the sediment column can be cored by the advanced piston coring technique to recover sediments with minimal drilling disturbance. The northward rate of tectonic displacement, however, is not so large that a traverse of the equatorial zone (within two degrees latitude of the equator) was too rapid to record a reasonable period of equatorial ocean history. Typically drill sites remain within the equatorial zone for 10-20 m.y. before passing beyond the northern edge of high biogenic sedimentation.

\section{The Flow Line Strategy and Equatorial Carbonate Compensation Depth}

The PEAT drilling program pursued a "flow line" rather than the "timeline" strategy pursued by previous ODP drilling legs for two reasons. A latitudinal transect (timeline) best resolves the structure of the equatorial current system, but for only a limited time window. Ocean crust cools and sinks as it ages, and the sea-floor on which the sediments are deposited approaches the lysocline and CCD within a few million years, especially during the Paleogene when the CCD was shallow. Thus, the best preserved part of sections recovered in such timeline transects is restricted by the depth at which carbonate dissolution significantly increases, as well as by the northward movement of sediment sections out of the region of high equa- 
torial productivity. This limitation was exemplified by the results from ODP Leg 199, which recovered only limited amounts of carbonate prior to the Eocene/Oligocene boundary (e.g., at ODP Site 1218 on 42-Ma-aged crust; Coxall et al., 2005).

Most paleoceanographic indices are measured on carbonates, so only a few million years at a time can be studied in detail via the timeline approach. It would take too long to drill the number of timeline transects needed to complete a Cenozoic history of the equatorial Pacific. Fortunately, the coherent response of the equatorial Pacific to climate events covers vast areas, so that one site drilled near the equator can be used to understand changes over much of the region. When this flow line strategy is linked to previous drilling, a synoptic view of the Pacific can be developed. The most recent ODP Legs 199 and 138 drilled along a line of equal oceanic crustal age, thus obtaining an approximate north-south transect across the major east-west currents during time intervals of particular interest.

For PEAT, we planned a flow line strategy to collect carbonate-bearing equatorial sediment sections through the Cenozoic (Fig. 2), making use of the

Pacific plate motion to add an oblique latitudinal transect across all time slices, and also exploiting crustal subsidence to collect limited paleodepth transects for certain time slices. We drilled a series of sites in the paleoequatorial region spanning key intervals of Cenozoic climate evolution. These intervals include the extremely warm early Eocene, the cooling of the late Eocene through Oligocene, the rela- $\delta^{18} \mathrm{O}(\%$ VPDB)

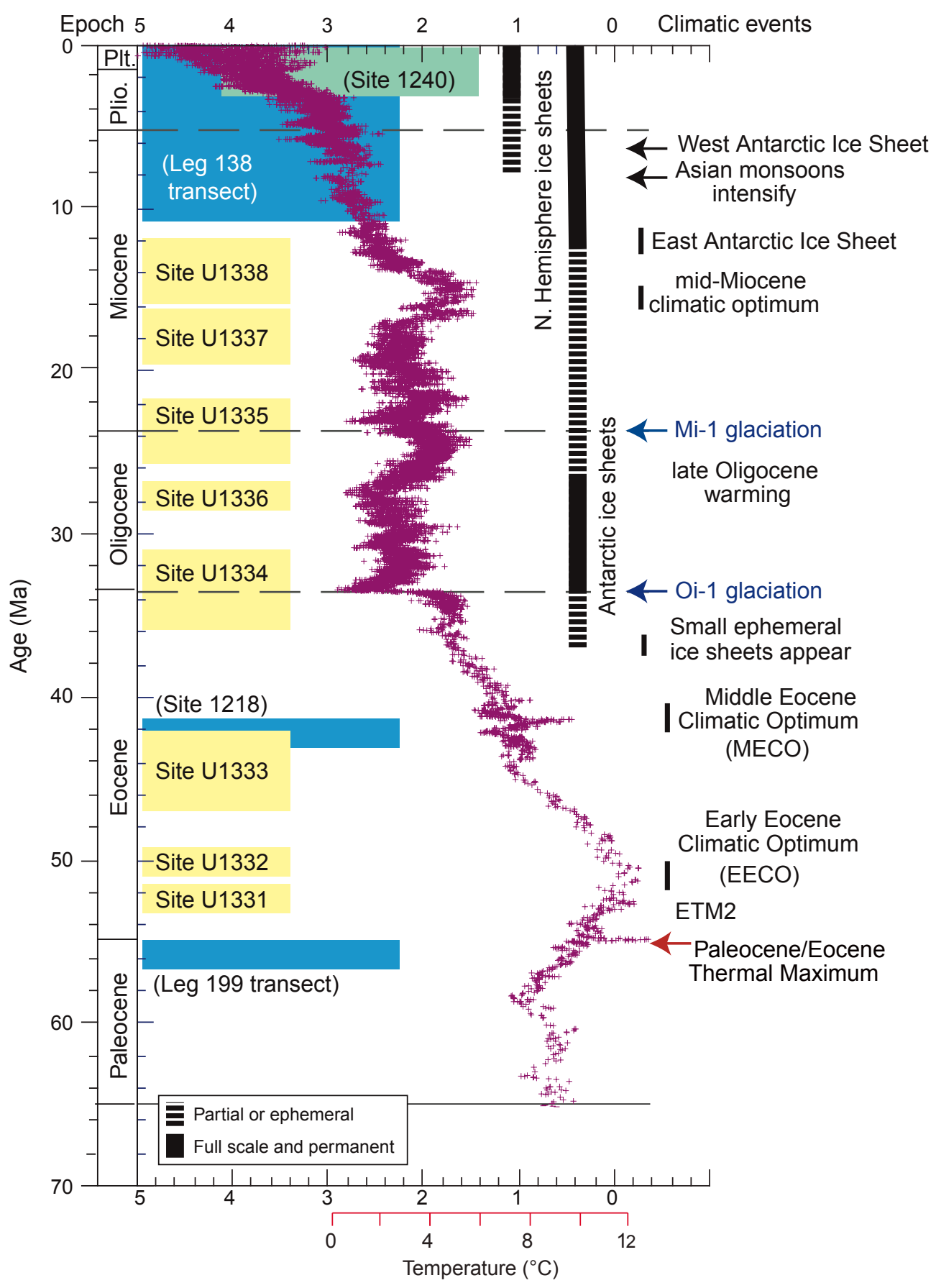

Figure 3. Evolution of oxygen stable isotopes $\left(\delta^{18} \mathrm{O}\right)$ through the Cenozoic and related major phases of climate change (modified from Zachos et al., 2001a, 2008). Yellow boxes = time slices of interest for the PEAT program, green and blue boxes = ODP legs and sites previously drilled in the equatorial Pacific region. These additional sites will be used with the PEAT sites to obtain a nearly continuous Cenozoic record of the equatorial Pacific region. $\mathrm{VPDB}=$ Vienna Peedee belemnite. Oi-1 = Oligocene isotopic Event $1, \mathrm{Mi}-1$ = Miocene isotopic Event 1 (Miller et al., 1991). ETM2 = Eocene thermal maximum 2. tively warm climates (or low ice volume) of the early Miocene, and sections deposited during development of major Southern and Northern Hemisphere ice sheets (Fig. 3). Each site was chosen close to the geographic paleoequator at critical age intervals on ocean crust slightly older than the intervals of particular interest. 


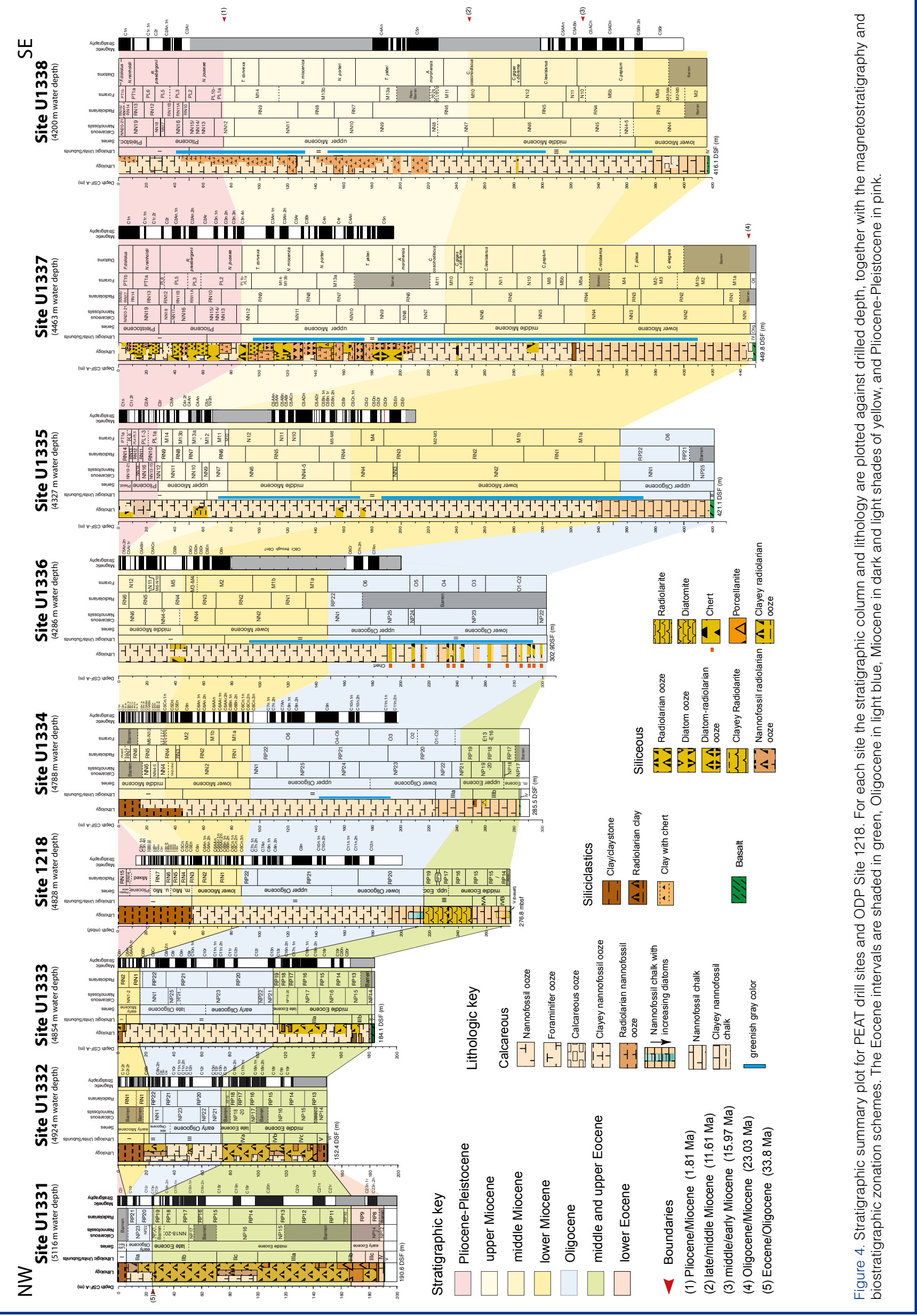


In this way we were able to track the paleoceanographic conditions at the paleoequator in the best preserved sediments obtainable. We can also make use of the high level of correlation between tropical sediment sections and seismic stratigraphy to develop a more complete model of equatorial productivity and sedimentation.

\section{Drilling Results}

Detailed descriptions of PEAT drilling can be found in the Exp 320 and Exp 321 Preliminary Reports (see Related Web Links), and in the Exp 320/321 Initial Reports (in press). Eight sites (U1331 to U1338) were drilled; their basement ages span from $52 \mathrm{Ma}$ to 18 Ma. PEAT shipboard science has determined that the sediments recovered fill gaps from previous

drill-ing and can be used to create a high-resolution megasplice of equatorial Pacific sedimentation. Cross-calibration of magneto-, bio-, and ultimately orbital stratigraphy will significantly improve chronological estimates of sedimentation and ages of significant events. The study of fluxes of different sediment components will then add a new dimension of information about biogeochemical cycling.

The PEAT program recovered sediments similar in lithology to previous DSDP and ODP expeditions to the central equatorial Pacific region (Lyle et al., 2002). Figure 4 summarizes the lithostratigraphy of the northwest-southeast transect of sites drilled during Expedition 320/321 together with the sedimentary sequence from ODP Site 1218, which is also included in the PEAT flow line strategy. As expected due to the decreasing age of crust toward the southeast, the Eocene sequence (Fig. 4, green shading) thins from northwest to southeast, pinching out east of Site U1334, the last site drilled on Eocene crust. In contrast, the Miocene sequence (Fig. 4, yellow shading) thickens substantially from northwest to southeast. The Miocene section is thickest at Site U1337, which targeted crust of latest Oligocene age, and thus is the drill site that spent the most time within the Miocene equatorial zone. The Oligocene sequence (Fig. 4, blue shading) is thickest in the middle of the PEAT transect (U1334 and U1336) and thins in both directions, marking the Oligocene equatorial zone.

The study of paleoceanographic processes-and the variations and evolution over time of mass accumulation rates across the PEAT transect-depend on a detailed knowledge of sedimentation rates. The integrated bio- and magnetostratigraphies obtained for all expedition sites are the starting point to allow us to fully exploit and understand the complex interplay of productivity, dissolution, and spatial biogenic sedimentation patterns. The sedimentation rates vary from site to site over time depending on crustal subsidence, crustal age, and the length of time spent in the equatorial region (Fig. 5).

Our results reveal the change of linear sedimentation rate in both the latitudinal and age transect components of the PEAT program. The comparison between sites reveals that the highest sedimentation rates occur within the Oligocene and Miocene equatorial zones (Sites U1334 to U1338), with sedimentation patterns similar to the modern equatorial region (highest deposition at the equator). However, sedimentation rates within the Eocene equatorial zone were not significantly higher than those outside of the equatorial zone. This result will be confirmed with revised estimates post-cruise of Pacific plate motion vectors. 
Time-dependent changes in sediment production and preservation strongly affected the Eocene sedimentary record. The linear sedimentation rates of the middle Eocene were high for the pelagic realm, frequently over $10 \mathrm{~m} \mathrm{m.y.}{ }^{-1}$, with a maximum of $18 \mathrm{~m} \mathrm{m.y.}{ }^{-1}$ at Site U1331. Rates for the middle Eocene at Sites U1332 and 1333 were similar (6-8 m m.y. $\left.{ }^{-1}\right)$. The sedimentation rates during the late Eocene decreased to 3.5-6 m m.y. ${ }^{-1}$ at Sites U1331 through U1333. Sediment-ation rates were highest (>20 m m.y. $\left.{ }^{-1}\right)$ during the early to late Oligocene at Sites U1333 and 1334, and in the early and middle Miocene at Sites U1337 and U1338.

All sites have either a hiatus or reduced sedimentation rates for the youngest sediments because they have moved out of the Neogene equatorial zone and into regions with low modern deposition rates. The data from the PEAT sites,when combined with available data from ODP Leg 138 for 0-10 Ma and ODP Leg 199 for intervals between $32 \mathrm{Ma}$ and $42 \mathrm{Ma}$ (Site 1218) and >52 Ma (Sites 1219 to 1221),-will produce a continuous history of sedimentation rates in the equatorial Pacific region for the past 56 m.y.

The combined results of ODP Leg 199 and the PEAT program provide the ability to study important intervals of climate change during the Cenozoic within the equatorial Pacific, and significant post-cruise research is aimed at these intervals. Important climate intervals include the early Eocene climatic optimum (EECO, Zachos et al., 2001a; Lyle et al., 2002; Sites U1331 and U1332), the middle Eocene climatic optimum (MECO; Bohaty and Zachos, 2003; Bohaty et al., 2009; Site U1333), the middle through late Eocene

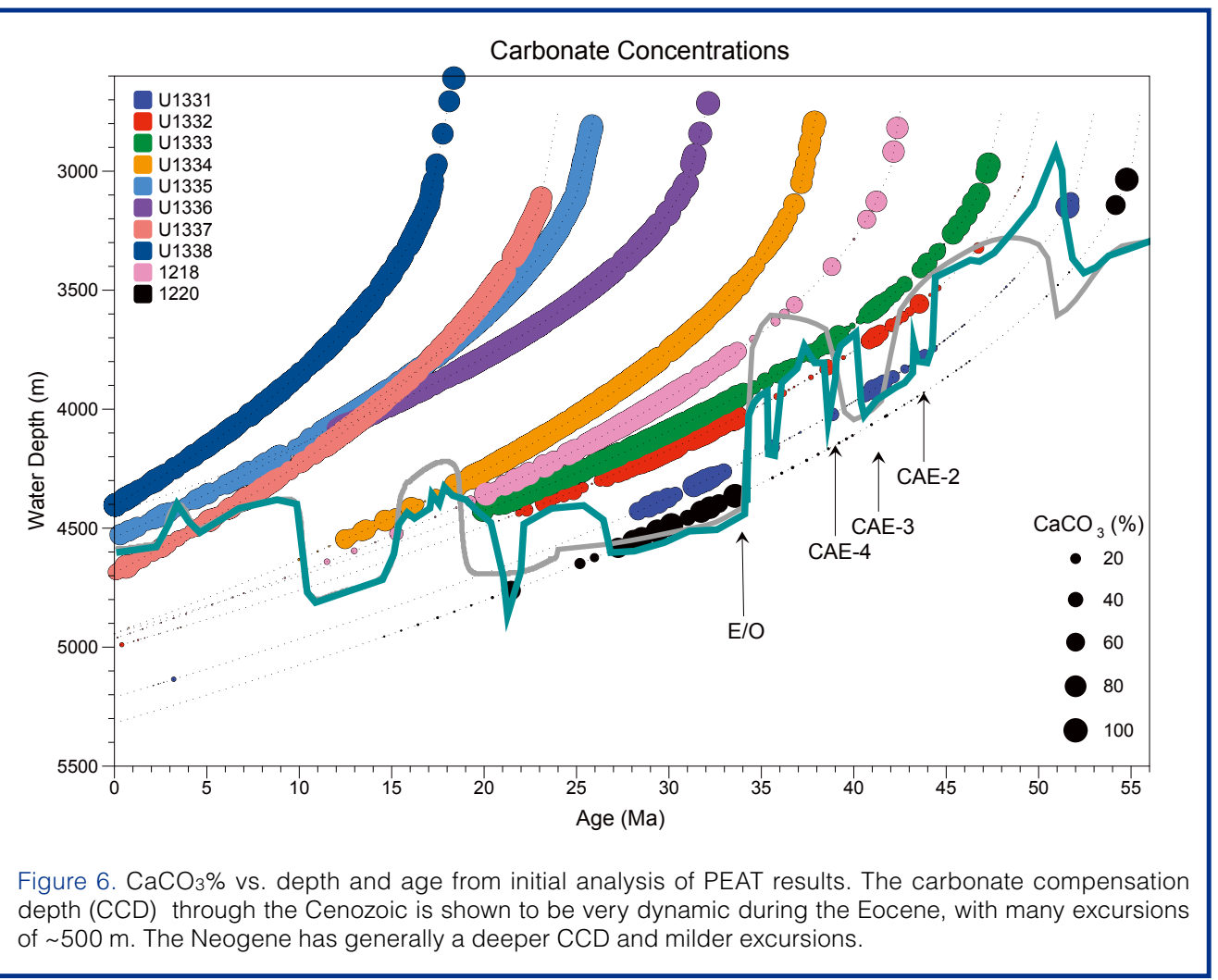

carbonate accumulation events (Lyle et al., 2005; Sites U1333 and U1334), the Eocene-Oligocene (EO) transition (Coxall et al., 2005; Site U1334), the late Oligocene warming (Pälike et al., 2006a; Site U1336), the Oligocene-Miocene (OM) transition (Zachos et al., 2001b; Pälike et al., 2006b; Sites U1335, U1336, and U1337), and the middle Miocene glaciation intensification event (Holbourn et al., 2005; Sites U1337 and U1338).

\section{Initial Results and Future Directions}

The highest shipboard priorities for a paleoceanographic drilling program are the development of a detailed sediment stratigraphy and the identification of a continuous sediment section that can be spliced together from multiple holes drilled at each site. In contrast, most of the scientific insight comes after drilling ceases and the scientific party has a chance to analyze samples collected from the cores along the spliced sedimentary sections. The sediment sampling was completed at the end of October 2009, and the analyses are just beginning. Nevertheless, broad-scale patterns can be discerned, and initial data have provided tantalizing indications of future results.

Because of the drilling design, the PEAT program was successful in collecting carbonate sediments of the late Eocene age and crossing the Eocene-Oligocene boundary. Carbonate sediments were also recovered for significant parts of the Eocene where it had been impossible from previous equatorial Pacific drilling to study the proxy climate information stored in carbonates. In addition, the Neogene PEAT sites are the first essentially complete Miocene sediment sections from the equatorial Pacific. These Miocene sediment sections will provide the first high-resolution studies of this poorly understood Cenozoic interval. Stable isotope studies on all the new sedimentary sequences will provide the backbone of information to understand the interrelationships between development of polar ice and equatorial circulation.

We also expect to recover important data about sea-surface temperature. Reconnaissance studies of alkenones (C. Beltran, unpublished) show a $4^{\circ} \mathrm{C}$ cooling of the equatorial Pacific since the middle Miocene. Most of the PEAT sediment splices are now being scanned using X-ray 
Fluorescence (XRF) to collect high-resolution profiles of chemical data for much of the time interval. Furthermore, quantitative studies of microfossil assemblages will give new insights into the changes in the equatorial Pacific ecosystem, including the development of a diatom-based ecology in the late middle Miocene, with significant monospecific diatom intervals during the transition (Kemp and Baldauf, 1993). Finally, downhole logging will enable refinement of the equatorial seismic stratigraphy developed by Mayer et al. (1985) from Deep Sea Drilling Project Leg 85.

One of the key achievements of the shipboard scientific program was better constraint of Cenozoic stratigraphy, showing the potential to achieve detailed bio-, magneto-, and chemostratigraphies for the Cenozoic from

the early Eocene to the present, within an astronomically tuned age model. Shipboard results indicate that we can achieve this objective based on the observation that even decimeter-scale features in the sedimentary record from the drilled sites can be correlated over large distances across the Pacific sea-floor (Pälike et al., 2005). The PEAT program will leave a lasting legacy through detailed correlation of all major fossil groups, a detailed magnetostratigraphy with over 800 dated reversals, and sedimentary cycles that can be correlated across large distances in the Pacific Ocean.

One of the primary objectives of the PEAT program is to detail the nature and changes of the $\mathrm{CCD}$ throughout the Cenozoic in the paleoequatorial Pacific (see text box on page 5), with potential links to organic matter deposition (Olivarez Lyle and Lyle, 2006). The choice of drilling locations, specifically targeting positions on the palaeoequatorto track carbonate preservation during crustal subsidence through time (Fig. 2)-followed the initial work on DSDP sites by van Andel et al. (1975). The first PEAT reconstruction of the Cenozoic CCD (Fig. 6) was augmented by additional results from ODP Leg 199 (Lyle et al., 2005; Rea and Lyle, 2005). One of the very significant contributions of Leg 199 drilling was the latitudinal mapping of CCD variations with time. During the Eocene, a generally shallow CCD appeared to be deeper outside a zone $\pm 4^{\circ}$ from the equator, opposite the pattern established during the Neogene (Lyle,
2003). The PEAT cores allow us to refine our knowledge of temporal and spatial variation in sediment accumulation rates resulting from plate movement, varying biologic productivity at the equatorial divergence, and carbonate preservation (Fig. 6). The shipboard determinations of $\mathrm{CaCO}_{3}$ concentrations reveal the carbonate accumulation events of Lyle et al. (2005) as sharp carbonate concentration fluctuations at $44 \mathrm{Ma}, 41 \mathrm{Ma}, 39 \mathrm{Ma}$, and $36 \mathrm{Ma}$ across Sites U1331 through U1334 and ODP Site 1218, followed by a sharp transition into much higher carbonate accumulation rates from the Eocene into the Oligocene. PEAT shipboard results reveal a complex Eocene latitudinal pattern, where Sites U1331, U1332, and U1334 track the equatorial CCD that well matches the signal observed from ODP Site 1218. On the other hand, Site U1333, which is slightly to the north of the equatorial zone during the E-O transition, shows significantly more carbonate accumulation.

The early Eocene equatorial CCD was much shallower than previously thought. Site U1332, drilled on 50-Ma crust, recovered very little carbonate in the basal sediment section, in contrast to Site U1331 that is just two million years older. The estimated equatorial Pacific CCD at $\sim 49 \mathrm{Ma}$ is $<3000 \mathrm{~m}$ paleodepth. Surprisingly, the late Oligocene (23-27 Ma) CCD was also found to be $300 \mathrm{~m}$ shallower than previously estimated. This shallower CCD, at a paleodepth of approximately $4.5 \mathrm{~km}$, along with associated reduced carbonate 
fluxes to the sea-floor, may be linked to a late Oligocene warming before the $\mathrm{O} / \mathrm{M}$ boundary. The $\mathrm{O} / \mathrm{M}$ boundary interval was first fully recovered in the equatorial Pacific at ODP Site 1218 (Fig. 3; see also suppl. Fig. 3 in Pälike et al., 2006a). Neogene carbonate minima are well documented in the Neogene PEAT sites, including a CCD minimum between $17 \mathrm{Ma}$ and $18 \mathrm{Ma}$, a 'carbonate crash' interval around $10 \mathrm{Ma}$, and a newly delineated CCD minimum at about $4 \mathrm{Ma}$ that occurs concurrently with enhanced deposition of diatomaceous sediments. The design of our drilling locations in combination with existing data will allow us to generate a three-dimensional view of Cenozoic CCD evolution during post-cruise research and to explore the linkage between Cenozoic changes in atmospheric $\mathrm{CO}_{2}$ and global warmth.

Post-cruise research will undoubtedly enhance our understanding of the strength and timing of the CCD events and how they relate to other globally important Earth systems. These studies are intended in part to develop the tie between these events and orbital insolation changes. Reaching a sample resolution high enough to detect orbital insolation variations is an important PEAT objective, necessary to improve the Cenozoic age model and to confirm that events across the equatorial Pacific are synchronous.
Initial XRF scanning results from the Neogene (Lyle et al., unpublished) using the new Texas A\&M XRF scanner at the IODP Gulf Coast Repository demonstrate how important information will result from detailed studies of the PEAT sediment (Fig. 7). Shown is a comparison between the 0-5 Ma XRF Ca peak area in Site U1338 and the Lisiecki and Raymo (2005) LR04 benthic oxygen isotope stack. The Ca peak area is correlated to the $\mathrm{CaCO} 3$ content in the $\mathrm{U} 1338$ sediments. The age model used in this example for U1338 is the linear shipboard age model, which has not been further tuned.

The benthic isotope record clearly shows a progression from low amplitude 41-kyr obliquity cycles to higher amplitude 41-kyr cycles at $2.7 \mathrm{Ma}$, and finally to the dominance of $100-k y r$ eccentricity cycles by $1 \mathrm{Ma}$. The development of the $100-\mathrm{kyr}$ power within the oxygen isotope record is most easily observed in the 100-kyr bandpass filtered isotope record. For the oxygen isotope record older than $1 \mathrm{Ma}$, the spectral power in the 100-kyr band is only about 0.2 times that of the 41-kyr band. The evolution of the benthic isotope record may be caused by the development of Northern Hemisphere ice sheets or at least increased sensitivity to

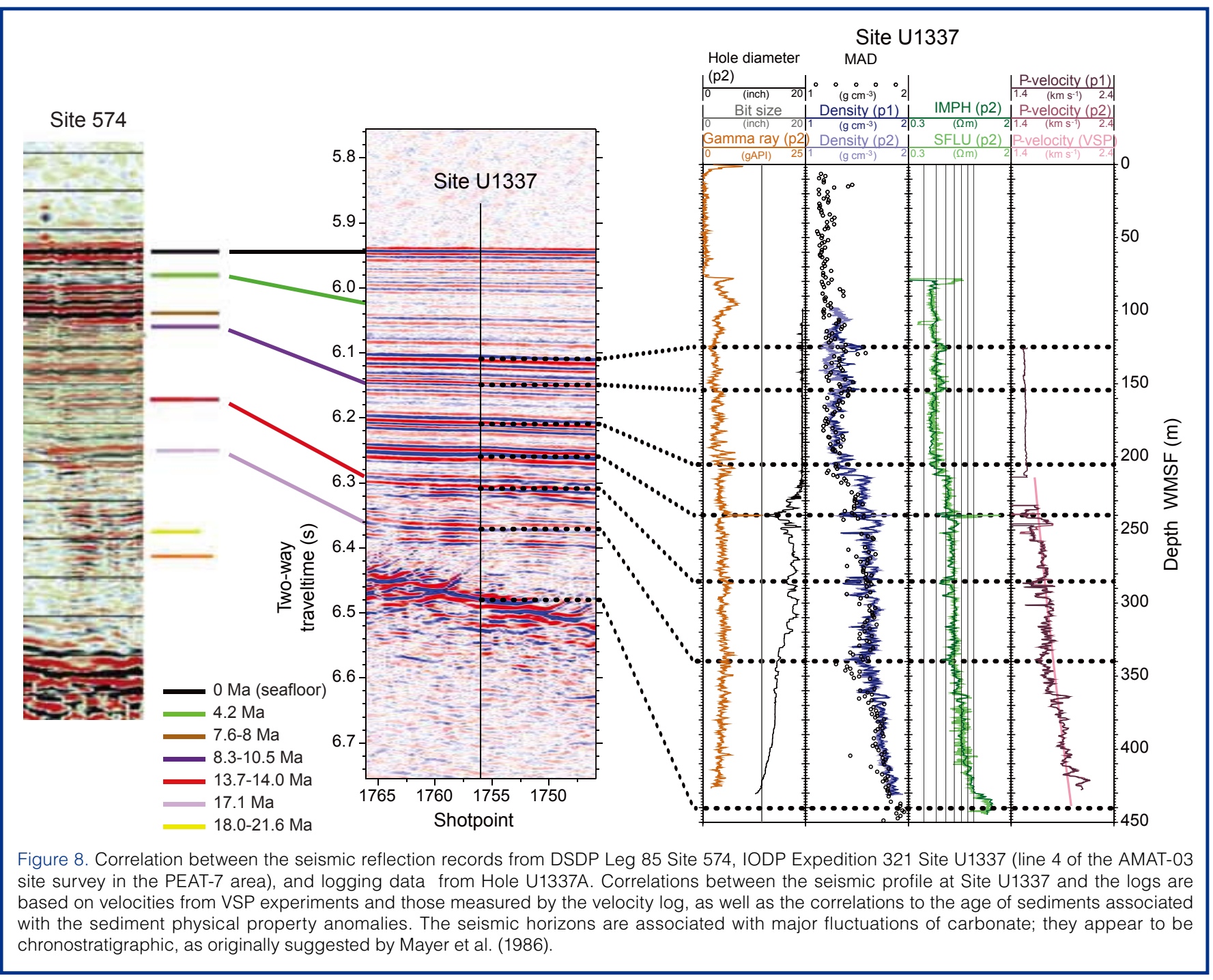


high latitude insolation prior to the late Pleistocene (Lisiecki and Raymo, 2005).

In contrast, the U1338 Ca record retains spectral power in the 100-kyr band throughout the five-million-year record, suggesting that there is a linkage between carbonate burial and eccentricity (Pälike et al., 2006a). For the interval older than $1 \mathrm{Ma}$, the $100-\mathrm{kyr}$ power in the Ca record is roughly six times greater than the $41-\mathrm{kyr}$ power. It is interesting to note that records for 0-6 Ma from ODP Leg 138 eastern Pacific sites did not record high 100-kyr power (Hagelberg et al., 1995), but they do find high variability associated with obliquity (41 kyr) and precession (23 kyr and $19 \mathrm{kyr}$ ). The significant level of 100-kyr power in the older, deeper PEAT site suggests that dissolution (changes in $\mathrm{CO}_{2}$ storage) may play a significant role in the development of the $\sim 100-\mathrm{kyr}$ $\mathrm{CaCO}_{3}$ cycle in the central Pacific. Furthermore, it leads to the speculation that the abyssal carbon cycle played a role in 'looking in' the glacial cycles to a 100 -kyr rhythm.

Another major objective of PEAT drilling was to groundtruth the equatorial Pacific seismic stratigraphy so that seismic reflection records can be used to connect the sediment column described at each drill site to form a regional model. The PEAT expeditions have collected important new physical property data so that we can confirm the Mayer et al. (1985) seismic stratigraphy and also tie the eastern Pacific seismic stratigraphy with that of the central Pacific.

The equatorial Pacific is a classic 'binary' sediment system, with variable amounts of biogenic calcium carbonate and biosiliceous sediment components but very little clay. It is also well known that carbonate contents of equatorial Pacific sediments can be estimated from the bulk density, because carbonates have lower porosity and higher grain density than biosiliceous sediments (Mayer, 1991). Consequently, physical properties records contain meter-scale cyclicity that will ultimately be useful for orbital-tuning time scales, which is one of the PEAT objectives. Mayer et al. (1985) developed a seismic stratigraphy for the central Pacific at Site 574 on DSDP Leg 85. They noted that major seismic horizons were caused by density variations associated with low carbonate intervals. They proposed that the seismic horizons were isochrons because they were caused by paleoceanographic changes in deposition and/or dissolution of calcium carbonate.

Mayer et al. (1985) did not have logs to measure in situ velocities in support of their interpretation. One of the important PEAT experiments therefore was to use a combination of downhole measurements (vertical seismic profile (VSP) and standard $\operatorname{logs}$ ) with physical properties measurements on core. We were able to run the VSP log at Site U1337 (Fig. 8) and Site U1338. Figure 8 is an initial comparison between the Site 574 seismic stratigraphy of Mayer et al. (1985) and the shipboard results for Site U1337. The events correlate in age, as would be predicted by Mayer et al. (1985). Site 574 is at essentially the same latitude as Site U1337 but is located more than $1000 \mathrm{~km}$ to the west. The extent of the correlatable seismic horizons across the Pacific helps to define the magnitude of the paleoceanographic events that caused them. Post-cruise studies will focus upon better defining the seismic strati-graphy at both Sites U1337 and U1338, allowing new tie points for seismic stratigraphic study of the equatorial Pacific sediment bulge (Mitchell et al., 2003).

\section{Outlook for the Future}

The initial results from PEAT drilling illustrate the fundamental thrusts of the post-cruise science and provide a taste of new scientific insights to be reported in the next few years. We expect these insights to include a fundamental improvement of the Cenozoic time scale, an exploration of the unstable Eocene $\mathrm{CCD}$ and its relation to atmospheric $\mathrm{CO}_{2}$, a much better understanding of the interactions between the carbon cycle and climate, and a better understanding of the history of major pelagic nutrient cycles and productivity. All of these studies will give important insights on how different Earth systems have interacted in the past and may respond in the near future.

\section{Acknowledgements}

We thank the ship's crew and drilling crew on the JOIDES Resolution, and the technical staff of the U.S. Implementing Organization who made it possible to translate our plans into recovered core. M. Lyle also acknowledges support from the U.S. Science Advisory Committee for his participation and for NSF grant OCE-07253011.

\section{References}

Bohaty, S.M., and Zachos, J.C., 2003. Significant Southern Ocean warming event in the late middle Eocene. Geology, 31(11):1017-1020, doi:10.1130/G19800.1.

Bohaty, S.M., Zachos, J.C., Florindo, F., and Delaney, M.L., 2009. Coupled greenhouse warming and deep-sea acidification in the middle Eocene. Paleoceanogr., 24: PA2207, doi:10.1029/ 2008PA001676, 16 pp.

Bryden, H.L., and Brady, E.C., 1985. Diagnostic model of the threedimensional circulation in the upper equatorial Pacific Ocean. J. Phys. Oceanogr., 15:1255-1273, doi:10.1175/15200485(1985)015<1255:DMOTTD >2.0.CO;2.

Cane, M.A., and Molnar, P., 2001. Closing of the Indonesian Seaway as a precursor to east African aridification around 3-4 million years ago. Nature, 411:157-162, doi:10.1038/35075500.

Cane, M.A., and Zebiak, S.E., 1985. A theory for El Niño and the Southern Oscillation. Science, 228:1085-1087、doi:10.1126/ science.228.4703.1085.

Chavez, F.P., and Barber, R.T., 1987. An estimate of new production in the equatorial Pacific. Deep Sea Res., 34:1229-1243, doi:10.1016/0198-0149(87)90073-2.

Coxall, H.K., Wilson, P.A., Pälike, H., Lear, C., and Backman, J., 2005. Rapid stepwise onset of Antarctic glaciation and deeper 
calcite compensation in the Pacific Ocean. Nature, 433:53-57, doi:10.1038/nature03135.

Hagelberg, T.K., Pisias, N.G., Mayer, L.A., Shackleton, N.J., and Mix, A.C., 1995. Spatial and temporal variability of late Neogene equatorial Pacific carbonate, Leg 138. In Pisias, N.G., Mayer, L.A., Janecek, T.R., Palmer-Julson, A., and van Andel, T.H. (Eds.), Proc. ODP, Sci. Results, 138, College Station, Texas (Ocean Drilling Program), 321-336.

Haug, G.H., and Tiedemann, R., 1998. Effect of the formation of the Isthmus of Panama on Atlantic Ocean thermohaline circulation. Nature, 393:673-676, doi:10.1038/31447.

Holbourn, A., Kuhnt, W., Schulz, M., and Erlenkeuser, H., 2005. Impacts of orbital forcing and atmospheric carbon dioxide on Mioceneice-sheetexpansion. Nature,438(7067):483-487, doi:10.1038/nature04123.

Hovan, S.A., 1995. Late Cenozoic atmosphere circulation intensity and climatic history recorded by eolian deposition in the eastern equatorial Pacific Ocean, Leg 138. In Pisias, N.G., Mayer, L.A., Janecek, T.R., Palmer-Julson, A., and van Andel, T.H. (Eds.), Proc. ODP, Sci. Results, 138, College Station, Texas (Ocean Drilling Program), 615-626.

Keigwin, L.D., 1982. Isotopic paleoceanography of the Caribbean and East Pacific: role of Panama uplift in Late Neogene time. Science, 217(4557):350-353, doi:10.1126/science.217.4557. 350 .

Kemp, A.E., and Baldauf, J.G., 1993. Vast Neogene laminated diatom mat deposits from the eastern equatorial Pacific Ocean. Nature, 362:141-143, doi:10.1038/362141a0.

Koppers, A.A.P., Morgan, J.P., Morgan, J.W., and Staudigel, H., 2001. Testing the fixed hotspot hypothesis using Ar-40/Ar-39 age progressions along seamount trails. Earth Planet. Sci. Lett., 185(3-4):237-252, doi:10.1016/S0012-821X(00)00387-3.

Lanci, L., Pares, J.M., Channell, J.E.T., and Kent, D.V., 2005. Oligocene magneto-stratigraphy from Equatorial Pacific sediments (ODP Sites 1218 and 1219, Leg 199). Earth Planet. Sci. Lett., 237:617-634, doi:10.1016/j.epsl.2005.07.004.

Lisiecki, L.E., and Raymo, M.E., 2005. A Pliocene-Pleistocene stack of 57 globally distributed benthic $\delta^{18}$ O records. Paleoceanogr., 21:PA1003, doi:1010.1029/2004PA001071, 17 pp.

Lyle, M., 2003. Neogene carbonate burial in the Pacific Ocean. Paleoceanogr., 18(3):1059, doi:10.1029/2002PA000777.

Lyle, M., Barron, J., Bralower, T.J., Huber, M., Olivarez Lyle, A., Ravelo, A.C., Rea, D.K., and Wilson, P.A., 2008. The Pacific Ocean and Cenozoic evolution of climate. Rev. Geophys., 46:RG2002, doi:10.1029/2005RG000190.

Lyle, M., Dadey, K., and Farrell, J., 1995. The Late Miocene (11-8 Ma) eastern Pacific carbonate crash: evidence for reorganization of deep water circulation by the closure of the Panama Gateway. In Pisias, N.G., Mayer, L.A., Janecek, T.R., PalmerJulson, A., and van Andel, T.H. (Eds.), Proc. ODP, Sci. Results, 138, College Station, Texas (Ocean Drilling Program), 821-837.

Lyle, M.W., Olivarez Lyle, A., Backman, J., and Tripati, A., 2005. Biogenic sedimentation in the Eocene equatorial Pacific: the stuttering greenhouse and Eocene carbonate compensation depth. In Lyle, M., Wilson, P., Janecek, T.R., and Firth, J. (Eds.), Proc. ODP, Sci. Results, 199, College Station, Texas (Ocean Drilling Program), 35 pp.
Lyle, M., Wilson, P.A., Janecek, T.R., and the ODP Leg 199 Shipboard Scientific Party, 2002. Proc. ODP Init. Repts., 199, College Station, Texas (Ocean Drilling Program).

Mayer, L.A., 1991. Extraction of high-resolution carbonate data for palaeoclimate reconstruction. Nature, 352:148-50, doi:10.1038/352148a0.

Mayer, L.A., Shipley, T.H., Theyer, F., Wilkens, R.H., Winterer, E.L., Seismic modeling and paleoceanography at Deep Sea Drilling Project Site 574. In: Mayer, L.A., Theyer, F., Thomas, E., et al., Init. Repts. DSDP 85: Washington, U.S. Govt. Printing Office, 947-970, 1985.

Mayer, L.A., Shipley, T.H., and Winterer, E.L., 1986. Equatorial Pacific seismic reflectors as indicators of global oceanographic events. Science, 233:761-764, doi:10.1126/science. 233.4765.761.

Miller, K.G., Wright, J.D., and Fairbanks, R.G., 1991. Unlocking the Ice House, Oligocene-Miocene oxygen isotopes, eustasy, and margin erosion. J. Geophys. Res., 96(B4):6829-6848, doi:10.1029/90JB02015.

Mitchell, N.C., Lyle, M.W., Knappenberger, M.B., and Liberty, L.M., 2003. The lower Miocene to present stratigraphy of the equatorial Pacific sediment bulge and carbonate dissolution anomalies. Paleoceanogr., 18:1038, doi:10.1029/2002PA 000828 .

Moore, T.C., Backman, J., Raffi, I., Nigrini, C., Sanfilippo, A., Pälike, H., and Lyle, M., 2004. The Paleogene tropical Pacific: clues to circulation, productivity, and plate motion. Paleoceanogr., 19:PA3013, doi:10.1029/2003PA000998.

ODP Leg 199 Shipboard Scientific Party, 2002. Leg 199 Summary. In Lyle, M.W., Wilson, P.A., Janecek, T.R. (Eds.), Proc. ODP, Init Repts., 199, College Station, Texas (Ocean Drilling Program), 1-87.

Olivarez Lyle, A., and Lyle, M.W., 2006. Missing organic carbon in Eocene marine sediments: is metabolism the biological feedback that maintains end-member climates? Paleoceanogr., 21:PA2007, doi:10.1029/2005PA001230.

Pälike, H., Moore, T., Backman, J., Raffi, I., Lanci, L., Parés, J.M., and Janecek, T., 2005. Integrated stratigraphic correlation and improved composite depth scales for ODP Sites 1218 and 1219. In Wilson, P.A., Lyle, M., and Firth, J.V. (Eds.), Proc. ODP, Sci. Results, 199, College Station, Texas (Ocean Drilling Program), 42 pp.

Pälike, H., Norris, R.D., Herrle, J.O., Wilson, P.A., Coxall, H.K., Lear, C.H., Shackleton, N.J., Tripati, A.K., and Wade, B.S., 2006a. The heartbeat of the Oligocene climate system. Science, 314(5807):1894-1898, doi:10.1126/science.1133822.

Pälike, H., Frazier, J., and Zachos, J.C., 2006b. Extended orbitally forced palaeoclimatic records from the equatorial Atlantic Ceara Rise. Quat. Sci. Rev., 25:3138-3149. doi:10.1016/j. quascirev.2006.02.011.

Philander, S.G.H., 1983. El Niño Southern Oscillation phenomena. Nature, 302:295-301, doi:10.1038/302295a0.

Pisias, N.G., Mayer, L.A., and Mix, A.C., 1995. Paleoceanography of the eastern equatorial Pacific during the Neogene: synthesis of Leg 138 drilling results. In Pisias, N.G., Mayer, L.A., Janecek, T.R., Palmer-Julson, A., and van Andel, T.H. (Eds.), Proc. ODP, Sci. Results, 138, College Station, Texas (Ocean Drilling Program), 5-21. doi:10.2973/odp.proc.sr.138.101. 1995. 
Rea, D.K., and Lyle, M., 2005. Paleogene calcite compensation depth in the eastern subtropical Pacific: answers and questions. Paleoceanogr., 20:PA1012, doi:10.1029/2004PA001064, 9 pp.

Romine, K., and Lombari, G., 1985. Evolution of Pacific circulation in the Miocene: radiolarian evidence from DSDP Site 289. In Kennett, J.P. (Ed.), The Miocene Ocean: Paleoceanography and Biogeography, GSA Memoir 163, Boulder, Colo. (Geological Society of America), 273-291.

Roth, J.M., Droxler, A.W., and Kameo, K., 2000. The Caribbean carbonate crash at the middle to late Miocene transition: linkage to the establishment of the modern global ocean conveyor. In Leckie, R.M., Sigurdsson, H., Acton, G.D., and Draper, G. (Eds.), Proc. ODP, Sci. Results, 165, College Station, Texas (Ocean Drilling Program), 249-273, doi:10.2973/odp.proc.sr.165.013.2000.

Schneider, D.A., 1995. Paleomagnetism of some Leg 138 sediments: detailing Miocene magnetostratigraphy. In Pisias, N.G., Mayer, L.A., Janecek, T.R., Palmer-Julson, A., and van Andel, T.H. (Eds.), Proc. ODP, Sci. Results, 138, College Station, Texas (Ocean Drilling Program), 59-72.

Shackleton, N.J., Crowhurst, S., Hagelberg, T., Pisias, N.G., and Schneider, D.A., 1995. A new late Neogene time scale: application to Leg 138 Sites. In Pisias, N.G., Mayer, L.A., Janecek, T.R., Palmer-Julson, A., and van Andel, T.H. (Eds.), Proc. ODP, Sci. Results, 138, College Station, Texas (Ocean Drilling Program), 73-101.

Takahashi, T., Feely, R.A., Weiss, R.F., Wanninkhof, R.H., Chipman, D.W., Sutherland, S.C., and Takahashi, T.T., 1997. Global air-sea flux of $\mathrm{CO}_{2}$ : an estimate based on measurements of sea-air $\mathrm{PCO}_{2}$ difference.Proc. Natl. Acad. Sci., 94:8292-8299, doi:10.1073/pnas.94.16.8292.

van Andel, T.H., 1975. Mesozoic/Cenozoic calcite compensation depth and global distribution of calcareous sediments. Earth Planet. Sci. Lett., 26:187-194, doi:10.1016/0012821X(75) 90086-2.

van Andel, T.H., Heath, G.R., and Moore, T.C., 1975. Cenozoic History and Paleoceanography of the Central Equatorial Pacific Ocean. A Regional Synthesis of Deep Sea Drilling Project Data. The Geological Society of America, Memoir 143, 134 pp.

Westberry, T.M., Behrenfeld, J., Siegel, D.A., and Boss, E., 2008. Carbon-based primary productivity modeling with vertically resolved photo-acclimation. Glob. Biogeochem. Cycles, 22:GB2024, doi:10.1029/2007GB003078.

Zachos, J.C., Dickens, G.R., and Zeebe, R.E., 2008. An early Cenozoic perspective on greenhouse warming and carbon-cycle dynamics. Nature, 451:279-283, doi:10.1038/nature06588.

Zachos, J.C., Pagani, M., Sloan, L., Thomas, E., and Billups, K., 2001a. Trends, rhythms, and aberrations in global climate 65 Ma to present. Science, 292:686-693, doi:10.1126/science. 1059412.

Zachos, J.C., Shackleton, N.J., Revenaugh, J.S., Pälike, H., and Flower, B.P., 2001b. Climate response to orbital forcing across the Oligocene-Miocene boundary. Science, 292(5515), 274-278, doi:10.1126/science.1058288.

\section{Authors}

Mitchell Lyle, Department of Oceanography, Texas A\&M University, TAMU 3146, College Station, TX 77840-3146, U.S.A., e-mail: mlyle@ocean.tamu.edu.

Heiko Pälike, School of Ocean and Earth Science, National Oceanography Centre, European Way, Southampton, SO14 3ZH, U.K., e-mail: heiko@noc.soton.ac.uk.

Hiroshi Nishi, Department of Natural History Sciences, Hokkaido University, Kita 10, Nishi 8, Kita-ku, Sapporo, 0600810, Japan, e-mail: hnishi@mail.sci.hokudai.ac.jp.

Isabella Raffi, Dipartimento di Geotecnologie per l'Ambiente eilTerritorio-DiGAT, Universitá “G.D’Annunzio”, Campus Universitario, via dei Vestini 31, 66013 Chieti Scalo, Italy, e-mail: raffi@unich.it.

Kusali Gamage, Integrated Ocean Drilling Program, Texas A\&M University, 1000 Discovery Drive, College Station, TX 77845-9547, U.S.A., e-mail: gamage@iodp.tamu.edu.

Adam Klaus, Integrated Ocean Drilling Program, Texas A\&M University, 1000 Discovery Drive, College Station, TX 77845-9547, U.S.A., e-mail: aklaus@iodp.tamu.edu.

\section{IODP PEAT (Exp. 320/321) Scientific Party}

Expedition 320: Heiko Pälike (co-chief scientist), Hiroshi Nishi (co-chief scientist), Adam Klaus (staff scientist), Gary Acton, Paul Bown, Margaret Delaney, Tom Dunkley Jones, Kirsty Edgar, Helen Evans, Peter Fitch, Nikolaus Gussone, Jens Herrle, Kiseong Hyeong, Shin-ichi Kamikuri, Junichiro Kuroda, Lizette Leon-Rodriguez, Theodore Moore Jr., Brandon Murphy, Hideto Nakamura, Christian Ohneiser, Carl Richter, Rebecca Robinson, Ken Sawada, Howie Scher, Hiroyuki Takata, Thomas Westerhold, Trevor Williams, Paul Wilson, and Yuhji Yamamoto.

Expedition 321: Mitchell Lyle (co-chief scientist), Isabella Raffi (co-chief scientist), Kusali Gamage (staff scientist), Louise Anderson, Jan Backman, Catherine Beltran, William Busch, James Channell, Pawan Dewangan, Hitoshi Hasegawa, Ed Hathorne, Hiroki Hayashi, Ann Holbourn, Steven Hovan, Koichi Iijima, Takashi Ito, Katsumori Kimoto, Alberto Malinverno, Daniel Murphy, Kaoru Ogane, Oscar Romero, Leah Schneider, Appy Sluijs, Jun Tian, Akira Tsujimoto, Bridget Wade, Roy Wilkens, Shinya Yamamoto, and Toshitsugu Yamazaki.

\section{Related Web Links}

http://iodp.tamu.edu/scienceops/expeditions/equatorial_ pacific.html http://www.iodp.org/Pacific-Equatorial-Age-TransectPEAT-1-2-Media-Kit/ 